\title{
Customer Bargaining Power and Accrual-Based Earnings Management
}

\author{
Tanweer Hasan \\ Independent University
}

\author{
Kevin Berry \\ Northern Michigan University \\ Stacy Boyer-Davis \\ Northern Michigan University
}

The present study provides a comprehensive analysis of the relationship between customer bargaining power and accrual-based earnings management using a sample of United States (U.S.) firms, with 16,084 firm-year observations, over the period 2000-2016. The absolute value of residuals from the modified-Jones model as described in Dechow et al. (1995) and the Kothari et al. (2005) models, respectively, were used as the proxy variable for the quality of accruals of a company. Results from the multivariate analysis, after controlling for firm-specific and market-specific variables, indicated that firms with high customer bargaining seem to engage more in opportunistic accrual management activities.

Keywords: earnings management, customer bargaining, accrual management, financial reporting

\section{INTRODUCTION}

The influence of customer-supplier relations on various financial and accounting policies has received a considerable amount of attention lately. This relatively recent strand of literature provides empirical evidence that customer-supplier relations significantly influence financial and accounting policies such as capital structure (Dhaliwal et al., 2016; Kale \& Shahrur, 2007; Banerjee et al., 2008; Chu, 2012; Huang \& Kim, 2019), disclosure choices (Ellis et al., 2012), and tax avoidance (Cen et al., 2017; Huang et al., 2016). Hui et al. (2012) argued that if suppliers or customers boast greater bargaining power, then companies on either side will recognize losses at a faster pace. Hui et al. (2012) and Krishnan et al. (2019) showed that customers' bargaining power or customer concentration is positively associated with accounting conservatism and audit quality, implying that a concentrated customer base is important to the achievement of high-quality financial reporting. The findings of Crawford et al. (2020) documented a negative relationship between customer concentration and management forecasts. These findings are consistent with customer concentration facilitating private information flow. Jung et al. (2020) found a negative relationship between customer concentration and income smoothing, while Deng and Yan (2019) showed that suppliers are more likely to engage in real earnings management with concentrated major customers.

Studies have also looked into the influence of customer-supplier relations, specifically on accrual management. Raman and Shahrur (2008) showed that discretionary accruals are positively associated with 
relationship-specific investment between customers and suppliers. Chen and Chen (2016) examined the impacts of capital expenditure and customer bargaining power on earnings management using exchangelisted companies in Taiwan and reported a positive correlation between the company's capital expenditure and its accrual-based earnings management. Furthermore, they show that the bargaining power of major customers has a positive influence on the accrual-based earnings management of a company. Kim and Lou (2021), using U.S. firms over a ten-year period (1997-2006), reported that Sarbanes Oxley (SOX) has led low-customer-concentration firms to reduce accrual-based earnings management more than high-customerconcentration firms have, suggesting that corporate governance to ensure high-quality earnings is more important when firms have lower customer concentration.

Given the limited empirical evidence on the influence of customer-supplier relation on accrual management, the present study adds to the current emerging stream of literature connecting customersupplier relation with a company's earnings management and takes a comprehensive look at the relationship between customer bargaining power and accrual management using two proxies for accrual management, the absolute value of residuals from the modified-Jones model as described in Dechow et al. (1995) and the absolute value of residuals from the modified-Jones model with return on assets (ROA) (Kothari et al., 2005). Also, following (Hui et al., 2012), two proxies for customer bargaining power, the HerfindahlHirschman Index (HHI) and major customer sales as a fraction of a supplier's total sales captured by all customers that account for more than $10 \%$ were used as test variables. Firm-specific and market-specific control variables, per the evidence reported in the literature, were also included in the multivariate model. Results reported in the present study using different proxies for accrual management and customer bargaining power show that firms where customers have high bargaining power, seem to engage more in opportunistic accrual management activities.

\section{HYPOTHESIS}

Customer bargaining power or concentration is a measure of how total revenue is distributed among a firm's customer base. If a firm has already acquired a large customer, it may not need to inflate earnings to attract another customer when the established customer-supplier relationship generates good performance. Suppliers do not have a strong need to signal their future performance for encouraging more relationshipspecific investments because their key customers are already well informed about them through costless private communication (Jung et al., 2020). Conversely, a supplier concerned about losing principal customers may have an incentive to inflate earnings to maintain its relationship with existing customers, especially when customers account for a large proportion of the total sales. A firm with a strong relationship with a major customer, indicating high customer concentration, may need to communicate more about its future cash flows to ensure the customer stays in the relationship. Even if the strong link to the customer keeps the customer more informed about the supplier, the customer cannot predict with certainty the supplier's future cash flows. A customer will evaluate its supplier's accounting performance and assess the risk of maintaining the current relationship. Thus, a supplier with high customer concentration may need to manage its earnings more to keep current customers and induce the customers to make relationship-specific investments. Therefore, it is hypothesized that customer concentration is positively related to earnings management.

\section{METHODOLOGY}

\section{Dependent Variable}

Accrual Management (AM1 and AM2)

Discretionary accruals are used as a measure of earnings management. Since the quality of the model varies according to the nature of the earnings management practice and bias can affect the estimation, Peasnell et al. (2000) recommend using more than one model to estimate discretionary accruals. In this study, both the modified-Jones (Dechow et al., 1995) and the Kothari et al. (2005) models are used. 
Jones (1991) provided a key model for determining expected accruals and unexpected or abnormal accruals. The Jones model assesses aggregate accruals by calculating the expected prediction error of total accruals from prior periods. Unlike previous accrual-based models (Healy, 1985; Deangelo, 1986; McNichols \& Wilson, 1988), the Jones model calculates the expected total accruals benchmark using the longest times series available for each firm. The prediction error calculated by the Jones model during the test period is compared to the prediction error for the event period, with significant differences identified as unexpected accruals. Jones recognized that economic circumstances could affect a firm's nondiscretionary accruals from period to period and accounted for this in the aggregate accruals model. Gross property, plant, and equipment (PPE) and changes in revenue were included in the expected accrual regression to control for changes in non-discretionary components to capture firms changing economic circumstances (Jones, 1991). The Jones model had implied that discretion over revenues during the estimation period and the period being assessed did not occur (Dechow et al., 1995). The modified-Jones model incorporated the change in receivables and the change in revenues in the event period. The modifiedJones model (Dechow et al., 1995) assumes that any changes in credit sales during the event period are the result of earnings management. Below is the modified-Jones model as described by Dechow et al. (1995): The absolute values of the residuals in this model were used as the first measure of earnings management (AM1).

$A C C_{i, \mathrm{t}}=a_{1}\left[1 /\left(A T_{i,-}-1\right)\right]+a_{2}\left[\left(\Delta R E V_{i, t}-\Delta \mathrm{A} R_{i, t}\right) /\left(A T_{i, t-1}\right)\right]+a_{3}\left[\left(P P E_{i, t}\right) /\left(A T_{i, t-1}\right)\right]+e_{i, t}$

where,

$A C C_{i, \mathrm{t}}=$ total accruals for firm $\mathrm{i}$ in year $\mathrm{t}$,

$\mathrm{AT}_{\mathrm{i}, \mathrm{t}-1}=$ total assets for firm $\mathrm{i}$ in year $\mathrm{t}-1$,

$\triangle \mathrm{REV}_{\mathrm{i}, \mathrm{t}}=\mathrm{a}$ change in revenues for firm $\mathrm{i}$ in year $\mathrm{t}$,

$\triangle \mathrm{AR}_{\mathrm{i}, \mathrm{t}}=\mathrm{a}$ change in accounts receivable for firm i in year $\mathrm{t}$,

$\mathrm{PPE}_{\mathrm{t}}=$ gross plant, property, and equipment for firm $\mathrm{i}$ in year $\mathrm{t}$.

Kothari et al. (2005) attempted to improve the accuracy of accrual model predictions in two ways: (1) including an intercept and (2) controlling for the effect of performance. Both the Jones model (1991) and the modified-Jones model (Dechow et al., 1995) are estimated without an intercept, which could magnify the misspecification of the accrual model. Kothari et al. included a constant term to mitigate misspecification problems arising from heteroskedasticity in residuals and omitted variables. To control for firm performance, Kothari et al. incorporated ROA in the accrual model. The Kothari et al. model, estimated as follows, is the Jones model with ROA and an intercept:

$$
\begin{aligned}
A C C_{i,}= & a_{1}+a_{2}\left[1 /\left(A T_{i,-1}\right)\right]+a_{3}\left[\left(\Delta R E V_{i, t}\right) /\left(A T_{i, t-1}\right)\right]+a_{4}\left[\left(P P E_{i, t}\right) /\left(A T_{i, t-1}\right)\right. \\
& +a_{5} R O A_{i, t}+e_{i, t}
\end{aligned}
$$

where,

$\mathrm{AT}_{\mathrm{i}, \mathrm{t}-1}=$ total assets for firm $\mathrm{i}$ in year $\mathrm{t}-1$,

$\triangle \mathrm{REV}_{\mathrm{i}, \mathrm{t}}=\mathrm{a}$ change in revenues for firm $\mathrm{i}$ in year $\mathrm{t}$,

$\mathrm{PPE}_{\mathrm{i}, \mathrm{t}}=$ gross plant, property, and equipment for firm $\mathrm{i}$ in year $\mathrm{t}$, and

$\mathrm{ROA}_{\mathrm{i}, \mathrm{t}}=$ net income over total assets; the equation above includes either $\mathrm{ROA}_{\mathrm{i}, \mathrm{t}}$

Absolute values of residuals from the Kothari et al. model, AM2, were used as the second measure of discretionary accruals.

\section{Test Variable(s)}

Customer Bargaining Power (CustBP1 and CustBP2)

Following Hui et al. (2012), two proxies for customer bargaining power, the Herfindahl-Hirschman Index (HHI) and Major Customer Sales, are used in the present study. HHI Customer Index (CustBP1): The 
Herfindahl-Hirschman Index (HHI) is used to measure the concentration of major customers. It is calculated as:

$\mathrm{HHI}=\sum\left(\mathrm{X}_{\mathrm{i}} / \mathrm{X}\right)^{2}$

where,

$$
\begin{aligned}
& X=\text { Total net sales of a company (supplier) } \\
& X_{i}=\text { net sales of a company to customer } i \\
& n=\text { The number of major customers of a company's sales. }
\end{aligned}
$$

\section{Major Customer Sales (CustBP2)}

The fraction of a supplier's total sales captured by all customers that account for more than $10 \%$. If a customer accounts for a high sales ratio of a supplier, then this customer enjoys bargaining power over its suppliers.

\section{Control Variables}

Firm Size (FSize)

Theoretical predictions regarding the relationship between firm size and earnings management (E.M.) are mixed. One view is that firm size may have a negative impact on E.M. due to a number of reasons. First, larger firms are more likely to design and maintain more sophisticated and effective internal control systems in comparison to smaller ones, reducing the likelihood of manipulating earnings by management (e.g., Beasley et al., 2000; Warfield et al., 1995). Second, large firms are more advantageous than small firms in terms of receiving better audit services from established audit firms due to larger operating budgets, which in turn could help prevent earnings misrepresentation (e.g., Gore et al., 2007; Francis et al., 1999; Becker et al., 1998; Payne \& Robb, 2000). Third, the relatively hefty reputation costs involved if the credibility of financial information disclosed by large firms is compromised and may prevent large firms from manipulating earnings. Fourth, stricter disclosure requirements by regulators on larger firms, which in turn reduces the information asymmetry, may discourage such firms from engaging in E.M. activity (Lee \& Choi, 2002). Fifth, larger firms are likely to be under closer scrutiny by outsiders than smaller firms (Watts \& Zimmerman, 1986). Such close scrutiny by outsiders can potentially reduce managers' opportunity to exercise their accounting discretion (Koh, 2003).

Another view is that firm size may have a positive impact on E.M. due to several reasons. First, capital market pressures to meet or beat the expectations of analysts and investment bankers are greater on larger firms creating the incentive for such firms to adopt aggressive accounting policies (Richardson et al., 2002; Barton \& Simko, 2002). Second, large firms have greater bargaining power with auditors making auditors more likely to waive E.M. attempts by large clients (Nelson et al., 2002). Third, large firms have more room to maneuver given the wide range of accounting treatments available. Fourth, although large firms may have a stronger internal control system, they also have more substantial management power, which may be used to override the internal control systems to manipulate earnings. Fifth, larger firms are more likely to exploit latitude in accounting discretion to reduce political attention by reducing reported earnings (Watts \& Zimmerman, 1978, 1986, 1990). In all, because of the contrasting views, we examine the relationship between firm size and E.M., but we do not conjecture the direction of the association.

Prior research has mixed findings with regard to size. While Becker et al. (1998), DeFond and Park (1997), and Beest et al. (2009) report a positive sign, Francis et al. (1999) and Reynolds and Francis (2000) report a negative coefficient for size. Meek et al. (2007) argue that earnings management may be lower in large firms because, compared to other firms; they have lower information asymmetry, stronger governance structures, and stronger external monitoring. The positive accounting theory suggested that managers of larger firms are more likely to engage in earnings management to reduce political costs (Watts \& Zimmerman, 1986). In contrast, managers of large firms have fewer opportunities to manage earnings because larger firms are more likely to be closely monitored by security analysts (Rajgopal et al., 1999). Large firms also have high-quality internal control and are usually audited by the Big 4 auditors, hence less 
likely to be able to hide abnormal accruals (Siregar \& Utama, 2008). Firm size, in the present study, is measured as Log (Total Assets).

\section{Sales Growth (SalesG)}

Sales growth is the first of the two variables used in the present study to control for firm growth. Firms with good growth opportunities need to raise external funds to expand (e.g., Lemma \& Negash, 2011), and such firms have the incentive to improve earnings quality to benefit from a lower cost of capital (Gaio, 2010). In the same vein, Shen and Chih (2007) remark that growth-firms that need external financing may find it optimal to improve their earnings quality and desist from E.M. activity since they are under close scrutiny by the market and therefore find it harder to fool the market by manipulating earnings. Thus, we expect an inverse relationship between growth opportunities and E.M. activities of a firm. Alternatively, the need to obtain external funding by growth-firms may create an incentive to try to signal a rosy picture about their future potential. Thus, it is possible that growth-firms may actively engage in earnings management activities (Richardson et al., 2002; Shen \& Chih, 2007). As a result, the relation between growth opportunities and earnings management is uncertain. Studies find that the level of accruals may depend on firms' growth characteristics (Young, 1999; Jones, 1991). Additionally, because growth and leverage are negatively related, it is important to include growth in an accrual model that includes leverage. Including leverage but not growth in the model may result in leverage picking up the effects of growth (Reynolds \& Francis, 2000). Sales growth, in the present study, is calculated as [(Sales - lagged Sales)/ lagged Sales].

\section{Market to Book Ratio (MB)}

Market to Book Ratio is the second variable used in the present study to control for firm growth. When growth slows, managers have more incentive to misstate financial statements in order to preserve the appearance of steady growth (Summer \& Sweeney, 1998). Growing firms are more sensitive to earnings forecasts, and thus a high M.B. ratio is expected to increase the use of earnings management (Chen et al., 2015). It is expected that firms with high growth tend to manage discretionary accruals upwards due because they are under the greatest pressure to adopt aggressive accounting policies to report increased earnings (Chih et al., 2008). The market to book ratio, in the present study, is defined as the market value of equity over its book value.

\section{Cash Flow From Operating Activities (OCF)}

It is expected that firms with a high level of cash flow are less likely to manage the accruals. Prior studies (Chen et al., 2007; Dechow, 1994; Dechow et al., 1995; DeFond \& Jiambalvo, 1994) found that firms' cash flow had a negative relationship with discretionary accounting accruals. High cash flow from operations results in high profits, and therefore, the firm will have less incentive to manipulate discretionary accounting accruals. This study controls for health since healthy firms are less likely to engage in incomeincreasing earnings management behavior (Becker et al., 1998). Cash flow from operating activities, in the present study, is calculated as (Cash Flows from Operating Activities / Lagged Total Sales).

\section{Audit Quality (AudQ)}

Becker et al. (1998) have examined the relationship between audit quality and earnings management by considering external auditing as a part of corporate governance. They assumed that Big-Six auditors were of higher quality than non-Big-Six auditors and found evidence that the clients of non-Big-Six auditors reported discretionary accruals, a proxy for earnings management, are on average, 1.5-2.1 percent of total assets higher than that reported by the clients of Big-Six auditors. Consistent with earnings management, they found that the mean and median of the absolute value of discretionary accruals were greater for firms audited by non-Big-Six auditors. Becker et al. (1998) also examine the variation in discretionary accruals, which they suggest reflects the accounting flexibility that the auditor allows. They documented that the companies audited by non-Big-Six auditors had significantly larger variation in discretionary accruals compared to the companies audited by Big-Six auditors over the sample period. They concluded that the 
test results were consistent with the external auditor acting as a constraint on management's opportunistic choice of accounting procedures, with the effectiveness of such constraint depending on auditor quality. High-quality auditing acts as an effective deterrent to earnings management activity.

Francis et al. (1999) have also examined whether the Big-Six auditors mitigate firms' earnings management behavior by constraining aggressive, potentially opportunistic reporting of accruals. They found that even though firms with the Big-Six auditors have a relatively higher level of total accruals, they had a smaller amount of estimated discretionary accruals compared to firms audited by the non-Big-Six auditors. They extended this analysis to the three levels of audit quality. Firms audited by the first-tier BigSix auditors had smaller discretionary accruals than firms audited by the second-tier national auditors, and firms audited by the second-tier national auditors had smaller discretionary accruals than firms audited by the third-tier local auditors. They contended that the Big-Six auditors had a greater ability to constrain management's aggressive and questionable accounting practices. Francis et al. (1999) also found evidence that high accrual firms hire Big-Six auditors to convey the credibility of their reported earnings to outside stakeholders of firms. High-quality auditing is, therefore, regarded as an element of effective corporate governance that reduces managerial opportunism in the area of corporate financial reporting.

Krishnan (2003) found evidence that the market attaches a higher value to the discretionary accruals audited by Big-Six auditors relative to the discretionary accruals audited by non-Big-Six auditors. Results showed that the association between stock returns and discretionary accruals was greater for firms audited by Big-Six auditors than for firms audited by non-Big-Six auditors. Further, the discretionary accruals of clients of Big-Six auditors have a greater association with future profitability than discretionary accruals of clients of non-Big-Six auditors. Krishnan (2003) argued that high-accrual firms faced greater agency costs compared to low-accrual firms and that auditing played an important role in mitigating those agency costs by constraining opportunistic management of accruals. Audit Quality, in the present study, is measured by a dummy variable equal to 1 if audited by big 4 or big 5 firms, 0 otherwise.

\section{Loss (LOSS)}

Loss is a measure of poor firm performance. There is a tendency for managers to use accruals in order to avoid reporting losses and earnings decreases. These firms are expected to have a strong incentive to manage earnings upward in order to report a positive earnings figure. Brown (2001) found that loss firms are less likely to report positive earnings surprises. Loss, in the present study, is measured as a dummy variable equal to 1 if the firm has negative net income in the current year.

\section{Financial Crisis (CRISIS)}

The 2007-2009 financial crisis was the most serious since the Great Depression, and it represented an exogenous and systematic shock to most firms. Prior studies showed that corporate governance, including boards of directors, was the most important factor in determining firm performance during crises (Johnson et al., 2000; Mitton, 2002; Francis et al., 2012). As there is no consensus as to the exact time window for the crisis, we designated fiscal years 2007 and 2008 as crisis years. Financial crisis, in the present study, is measured as a dummy variable equal to 1 if the fiscal year is equal to 2008 or 2009 , and 0 otherwise. The conjecture is that the firms, in general, may have been more involved in accrual management during the crisis years.

\section{Leverage (LEV)}

Higher debt is likely to attract stronger monitoring by debt-holders suggesting that there would be little room for opportunistic behavior, and hence E.M. activity, by management. Earlier studies documented that firms facing financial constraints or distress have strong incentives to utilize income-increasing accounting procedures to lower the potential loss arising from a violation of debt contracts (Dichev \& Skinner, 2002; Jaggi \& Lee, 2002; Sweeney, 1994). This argument would predict a positive relationship between the financial leverage ratio and discretionary accruals. Press and Weintrop (1990) confirmed that managers would favorably manage the earnings when their companies are highly leveraged. However, Kim et al. (2003) suggested that as a firm becomes highly leveraged, its ability to boost earnings through income- 
increasing accruals becomes weaker. Duke and Hunt (1990) suggested that when the debt covenant restrictions were related to retained earnings, working capital, and net tangible assets, managers were more likely to manipulate the debt to equity ratio to meet the debt covenant restrictions. Therefore, a positive association between the debt to equity ratio and income-increasing activity is predicted.

Leverage is used as a proxy for debt covenant violation (Elayan et al., 2008). The findings of the impact of Leverage on earnings management were mixed (Dechow \& Skinner 2000; DeFond \& Jiambalvo, 1994; Watts \& Zimmerman, 1990). Therefore, financial leverage can be negatively or positively associated with earnings management. Following Athanasakou and Olsson (2016), LEV, in the present study, is calculated as Long Term Debt to Total Assets.

\section{Sarbanes-Oxley Act (SOX)}

Research has shown that SOX led to enhanced governance standards of public firms (e.g., Chhaochharia \& Grinstein, 2007; Kedia et al., 2011). Lobo and Zhou (2006) found that there was an increase in accounting conservatism following the passage of SOX. Kim and Lou (2021) reported that SOX has led low-customer-concentration firms to reduce accrual-based earnings management more than highcustomer-concentration firms have, suggesting that corporate governance to ensure high-quality earnings is more important when firms have lower customer concentration. SOX, in the present study, was proxied by a dummy variable equal to 1 in the Post-Sarbanes Oxley period (fiscal year is equal to or greater than 2003), and 0 otherwise.

\section{Model}

The following multivariate model is used in the present study. A positive coefficient on the variable CustBP would mean that there is support for the hypothesis.

$\mathrm{AM}=\beta_{0}+\beta_{1}$ CustBP $+\beta_{2}$ FSize $+\beta_{3}$ SalesG $+\beta_{4}$ OCF $+\beta_{5}$ AudQ $+\beta_{6}$ Loss + $\beta_{7}$ FCrisis $+\beta_{8}$ Lev $+\mathrm{B}_{9} \mathrm{MB}+\beta_{10} \mathrm{SOX}+\varepsilon$

\section{Dependent Variable}

$\mathrm{AM}=$ Discretionary Accrual

AM1 = Absolute value of residuals from the modified-Jones model (Dechow et al., 1995)

$\mathrm{AM} 2=$ Absolute value of residuals from the Kothari (2005) model

\section{Test Variable}

CustBP = Customer Bargaining Power

CustBP1 = Major Customer Sales

CustBP2 = HHI Customer Index

\section{Control Variables}

FSize $=$ Log (Cash Flows from Operating Activities $)$

sales $=$ Year over year Sales Growth

$\mathrm{MB}=$ Market to Book Ratio

$\mathrm{OCF}=$ Cash Flow from Operating Activities

AudQ = Audit Quality

LOSS = Dummy variable equal to 1 if the firm has negative net income in the current year

CRISIS = Financial Crisis, a dummy variable equal to 1 if the fiscal year is equal to 2008 or 2009, and 0 otherwise

LEV $=$ Leverage

SOX $=$ Dummy variable equal to 1 in the Post-Sarbanes Oxley period (fiscal year is equal to or greater than 2003), and 0 otherwise. 


\section{Data}

U.S. firm data was collected from the Compustat fundamental annual data files for the period 20002016. Compustat's segment customer files were used to identify suppliers that disclose sales to major corporate customers. When calculating the dependent variables, Cash Flows from Operating Activities were truncated (winsorized) at the $1^{\text {st }}$ and 99th percentile. This was done to mitigate the influence of outliers and potential data errors. All of the continuous independent variables were also truncated at the $1^{\text {st }}$ and 99th percentile. This resulted in a total of 16,084 firm-year observations. Table 1 in the Appendix provides descriptive statistics, the mean, standard deviation, and the minimum and maximum for each of the variables.

\section{EMPIRICAL RESULTS}

The results from the multivariate model using the modified-Jones model (AM1) as the dependent variable are presented in Table 2 in the appendix. Table 2 presents the predicted sign as well as the parameter estimate, t-statistic ( $p$-value), and variance inflation factor for the two regression models run. The first model uses the Herfindal-Hirschman Index (CustBP1) as the proxy for customer bargaining power, the test variable. The results indicate that CustBP1 is positive, the predicted sign, and significant at the pvalue $<.05$ level. Three of the control variables, LOSS, LEV, and M.B., were significant at the $p$-value < .05 level, while three other control variables, FSize, Audi, and CRISIS, were significant at the $p$-value < .01 level. All of the control variables that were significant had the predicted sign. The second model estimated used major customer sales (CustBP2) as the proxy for customer bargaining power, the test variable. The results indicate that CustBP2 is positive, the predicted sign, and significant at the $p$-value < .01 level. Two of the control variables, LOSS, and LEV were significant at the p-value $<.05$ level. The same three control variables, FSize, Audi, and CRISIS, as the first model estimated, were significant at the $p$-value $<.01$ level. Again, all of the control variables that were significant had the predicted sign. The variance inflation factors indicated that multicollinearity was not a problem.

Table 3 in the Appendix presents the results from the multivariable model where the dependent variable was calculated using Kothari et al. (2005) AM2. Table 3 presents the predicted sign as well as the parameter estimate, t-statistic (p-value), and variance inflation factor for the two regression models run. The first model uses the Herfindal-Hirschman Index (CustBP1) as the proxy for customer bargaining power, the test variable. The results indicate that CustBP1 is positive, the predicted sign, and significant at the $p$-value < .01 level. The control variables FSize, OCF, LOSS, CRISIS, LEV, and M.B. were all significant at the $p$ value $<.01$ level, while three other control variables, FSize, Audi, and CRISIS, were significant at the $p$ value $<.01$ level and of the predicted sign. The second model used major customer sales (CustBP2) as the proxy for customer bargaining power, the test variable. The results indicate that CustBP2 is positive, the predicted sign, and significant at the $p$-value $<.01$ level. Again, the control variables FSize, OCF, LOSS, CRISIS, LEV, and M.B. were all significant at the $p$-value $<.01$ level while three other control variables, FSize, Audi, and CRISIS, were significant at the $p$-value $<.01$ level and of the predicted sign. The variance inflation factors indicated that multicollinearity was not a problem.

\section{CONCLUSION}

The present study provides a comprehensive analysis of the relationship between customer bargaining power and accrual-based earnings management using a sample of U.S. firms, with 16,084 firm-year observations, over the period 2000-2016. Alternate measures of customer bargaining power are used: (1) HHI Customer and (2) major customer sales fraction of a supplier's total sales captured by all customers that account for more than $10 \%$. The absolute value of residuals from the modified-Jones model as described in Dechow et al. (1995) and Kothari et al. (2005) models, respectively, are used as the proxy variable for the quality of accruals of a company. Results from the multivariate analysis, after controlling for firm-specific and market-specific variables, indicated that firms with high customer bargaining seem to engage more in opportunistic accrual management activities. These results are consistent with those of Kim 
and Lou (2021). The results also parallel those of Deng and Yan (2019) that found that high customer bargaining power were more likely to take part in real earnings management.

\section{REFERENCES}

Athanasakou, V.E., \& Olsson, P. (2016, January 14). Managerial Discretion and Firm Fundamentals. Canadian Academic Accounting Association (CAAA) Annual Conference. Retrieved from https://ssrn.com/abstract=2715636 or http://dx.doi.org/10.2139/ssrn.2715636

Banerjee, S., Dasgupta, S., \& Kim, Y. (2008). Buyer-supplier relationships and the stakeholder theory of capital structure. Journal of Finance, 63(5), 2507-2552. http://dx.doi.org/10.1111/j.15406261.2008.01403.x

Barton, J., \& Simko, P. (2002). The balance sheet as an earnings management constraint. The Accounting Review, 77(suppl. 1), 1-27. Retrieved from https://www.jstor.org/stable/3203322

Beasley, M.S., Carcello, J.V., Hermanson, D.R., \& Lapides, P.D. (2000). Fraudulent financial reporting: Consideration of industry traits and corporate governance mechanisms. Accounting Horizons, 14(4), 441-454. https://doi.org/10.2308/acch.2000.14.4.441

Becker, C.L., Defond, M.L., Jiambalvo, J., \& Subramanyam, K.R. (1998). The effect of audit quality on earnings management. Contemporary Accounting Research, 15(1), 1-24. https://doi.org/10.1111/j.1911-3846.1998.tb00547.x

Beest, F.V., Braam, G., \& Boelens, S. (2009, April). Quality of financial reporting: Measuring qualitative characteristics. NiCE Working Paper 09-108.

Brown, L.D. (2001). A temporal analysis of earnings surprises: Profits versus losses. Journal of Accounting Research, 39(2), 221-41. https://doi.org/10.1111/1475-679X.00010

Cen, L., Maydew, E.L., Zhang, L., \& Zuo, L. (2017). Customer-supplier relationships and corporate tax avoidance. Journal of Financial Economics, 123(2), 377-394. https://doi.org/10.1016/j.jfineco.2016.09.009

Chen, S., \& Chen, L. (2016). The Effects of customers' bargaining power on capital expenditure and earnings management: Evidence from Taiwan. Accounting and Finance Research, 5(3), 12-28. https://doi.org/10.5430/afr.v5n3p12

Chen, X., Cheng, Q., \& Wang, X. (2015). Does increased board independence reduce earnings management? Evidence from recent regulatory reforms. Review of Accounting Studies, 20(2), 899-933. https://doi.org/10.1007/s11142-015-9316-0

Chen, K.Y., Elder, R.J., \& Hsieh, Y.M. (2007). Corporate governance and earnings management: The implications of corporate governance best-practice principles for Taiwanese listed companies. Journal of Contemporary Accounting \& Economics, 3(2), 73-105. https://doi.org/10.1016/S1815-5669(10)70024-2

Chhaochharia, V., \& Grinstein, Y. (2007). Corporate governance and firm value: The impact of the 2002 governance rules. Journal of Finance, 62(4), 1789-825. https://doi.org/10.1111/j.1540-6261.2007.01257.x

Chih, H., Shen, C., \& Kang, F. (2008). Corporate social responsibility, investor protection, and earnings management: Some international evidence. Journal of Business Ethics, 79(2), 179-198. https://doi.org/10.1007/s10551-007-9383-7

Chu, Y. (2012). Optimal capital structure, bargaining, and the supplier market structure. Journal of Financial Economics, 106(2), 411-426. http://doi.org/10.1016/j.jfineco.2012.05.010

Crawford, S., Ying, H., Ningzhong, L., \& Ziyun, Y. (2020). Customer concentration and public disclosure: Evidence from management earnings and sales forecasts. Contemporary Accounting Research. https://doi.org/10.1111/1911-3846.12526

Deangelo, L. (1986). Accounting numbers as market value substitutes: A study of managerial buyouts of public stockholders. The Accounting Review, 61(30), 400-420. Retrieved from http://www.jstor.org/stable/247149 
Dechow, P.M., \& Skinner, D.J. (2000). Earnings management: Reconciling the views of accounting academics, practitioners, and regulators. Accounting Horizons, 14(2), 235-250. http://dx.doi.org/10.2139/ssrn.218959

Dechow, P.M. (1994). Accounting earnings and cash flows as measures of firm performance: The role of accounting accruals. Journal of Accounting and Economics, 17(1), 3-42. https://doi.org/10.1016/0165-4101(94)90016-7

Dechow P.M., Sloan R.G., \& Sweeney A.P. (1995). Detecting earnings management. The Accounting Review, 70(2), 193-225. Retrieved from http://www.jstor.org/stable/248303

DeFond, M., \& Park, C. (1997). Smoothing income in anticipation of future earnings. Journal of Accounting and Economics, 23(2), 115-139. https://doi.org/10.1016/S0165-4101(97)00004-9

DeFond, M.L., \& Jiambalvo, J. (1994). Debt covenant violation and manipulation of accruals. Journal of Accounting and Economics, 17(2), 145-176. https://doi.org/10.1016/0165-4101(94)90008-6

Deng, M., \& Yan, Y. (2019, July 29). Do suppliers benefit from customer concentration: Evidence from real earnings management. Baruch College Zicklin School of Business Research Paper (Report No. 2019-09-03). http://dx.doi.org/10.2139/ssrn.3444688

Dhaliwal, D., Judd, J.S., Serfling, M., \& Shaikh, S. (2016). Customer concentration risk and the cost of equity capital. Journal of Accounting and Economics, 61(1). https://doi.org/10.1016/j.jacceco.2015.03.005

Dichev, I., \& Skinner, D.J. (2002). Large-sample evidence on the debt covenant hypothesis. Journal of Accounting Research, 40(4), 1091-1123. https://doi.org/10.1111/1475-679X.00083

Duke, J., \& Hunt, H., III. (1990). An empirical examination of debt covenant restrictions and accountingrelated debt proxies. Journal of Accounting and Economics, 12(1), 45-63. https://doi.org/10.1016/0165-4101(90)90041-2

Elayan, F.A., Li, J., \& Meyer, T.O. (2008). Accounting irregularities, management compensation structure and information asymmetry. Accounting \& Finance, 48(5), 741-760. https://doi.org/10.1111/j.1467-629X.2008.00266.x

Ellis, J.A., Fee, C.E., \& Thomas, S.E., (2012). Proprietary costs and the disclosure of information about customers. Journal of Accounting Research, 50(3), 685-727. https://doi.org/10.1111/j.1475-679X.2012.00441.x

Francis, J.R., Maydew, E.L., \& Sparks, H.C. (1999). The role of big 6 auditors in the credible reporting of accruals. Auditing: A Journal of Practice \& Theory, 18(2), 17-34. https://doi.org/10.2308/aud.1999.18.2.17

Francis, B., Hasan, I., \& Wu, Q. (2012). Do corporate boards matter during the current financial crisis? Review of Financial Economics, 21(2), 39-52. https://doi.org/10.1016/j.rfe.2012.03.001

Gaio, C. (2010). The relative importance of firm and country characteristics for earnings quality around the world. European Accounting Review, 19(4), 693-738. doi:10.1080/09638180903384643

Gore, P., Pope, P.F., \& Singh, A.K. (2007). Earnings management and the distribution of earnings relative to targets: U.K. evidence. Accounting and Business Research, 37(2), 123-149. https://doi.org/10.1080/00014788.2007.9730065

Healy, P. (1985). The impact of bonus schemes on the selection of accounting principles. Journal of Accounting and Economics, 7(1), 85-107. https://doi.org/10.1016/0165-4101(85)90029-1

Huang, H.H., Lobo, G.J., Wang, C., \& Xie, H. (2016). Customer concentration and corporate tax avoidance. Journal of Banking \& Finance, 72, 184-200. https://doi.org/10.1016/j.jbankfin.2016.07.018

Huang, Q., \& Kim, R. (2019). Capital structure decisions along the supply chain: Evidence from import competition. Journal of International Business Studies, 50, 873-894. https://doi.org/10.1057/s41267-019-00225-9

Hui, K.W., Klasa, S., \& Yeung, P.E. (2012). Corporate suppliers and customers and accounting conservatism. Journal of Accounting and Economics, 53(1-2), 115-135. http://dx.doi.org/10.1016/ 
Jaggi, B., \& Lee, P. (2002). Earnings management response to debt covenant violations and debt reconstruction. Journal of Accounting, Auditing and Finance, 17(4), 295-324. https://doi.org/10.1177\%2F0148558X0201700402

Johnson, S., Boone, P., Breach, A., \& Friedman, E. (2000). Corporate governance in the Asian financial crisis. Journal of Financial Economics, 58(1), 141-186. https://doi.org/10.1016/S0304405X(00)00069-6

Jones, J. (1991). Earnings management during import relief investigations. Journal of Accounting Research, 29(2), 193-228. https://doi.org/10.2307/2491047

Jung, B., Kim, T.W., Park, S.H., \& Yoon, S.W. (2020, November 10). Customer concentration and income smoothing activities. Retrieved from https://ssrn.com/abstract=3728340 or http://dx.doi.org/10.2139/ssrn.3728340

Kale, J.R., \& Shahrur, H. (2007). Corporate capital structure and the characteristics of suppliers and customers. Journal of Financial Economics, 83(2), 321-365. https://doi.org/10.1016/j.jfineco.2005.12.007

Kedia, S., \& Rajgopal, S. (2011). Do the SEC's enforcement preferences affect corporate misconduct? Journal of Accounting and Economics, 51(3), 259-278. https://doi.org/10.1016/j.jacceco.2011.01.004

Kim, J., Chung, R., \& Firth, M. (2003). Auditor conservatism, asymmetric monitoring, and earnings management. Contemporary Accounting Research, 20(2), 323-359. https://doi.org/10.1506/J29K-MRUA-0APP-YJ6V

Kim, R., \& Luo, W. (2021). Customer concentration and earnings management: Evidence from the Sarbanes-Oxley Act. The European Accounting Review, pp. 1-32. https://doi.org/10.1080/09638180.2020.1858915

Koh, P.S. (2003). On the association between institutional ownership and aggressive corporate earnings management in Australia. The British Accounting Review, 35(6), 105-128. https://doi.org/10.1111/j.1467-8683.2005.00472.x

Kothari, S., Leone, A., \& Wasley, C. (2005). Performance matched discretionary accrual measures. Journal of Accounting \& Economics, 39(1), 163-197. https://doi.org/10.1016/j.jacceco.2004.11.002

Krishnan, G.V., Patatoukas, P.N., \& Wang, A.Y. (2019). Customer-base concentration: Implications for audit pricing and quality. Journal of Management Accounting Research, 31(1), 129-52. https://doi.org/10.2308/jmar-52040

Krishnan, G. (2003). Does big 6 auditor industry expertise constrain earnings management? Accounting Horizons, 17(Suppl. 1), 1-16.

Lee, B.B., \& Choi, B. (2002). Company size, auditor type, and earnings management. Journal of Forensic Accounting, 3, 27-50.

Lemma, T.T., \& Negash, M. (2011). Rethinking the antecedents of capital structure of Johannesburg Securities Exchange-listed firms. Afro-Asian Journal of Finance and Accounting, 2(4), 299-332. https://doi.org/10.1504/AAJFA.2011.043867

Lobo, G., \& Zhou, J. (2006). Did conservatism in financial reporting increase after the Sarbanes-Oxley Act? Initial evidence. Accounting Horizons, 20(1), 57-73. https://doi.org/10.2308/ACCH.2006.20.1.57

McNichols, M.F., \& Wilson, G.P. (1988). Evidence of earnings management from the provision for bad debts. Journal of Accounting Research, 26(suppl.), 1-31.

Meek, G.K., Roa, R.P., \& Skousen, C.J. (2007). Evidence on factors affecting the relationship between CEO stock option compensation and earnings management. Review of Accounting and Finance, 6(3), 304-323. https://doi.org/10.1108/14757700710778036

Mitton, T. (2002). A cross-firm analysis of the impact of corporate governance on the East Asian financial crisis. Journal of Financial Economics, 64, 215-241. https://doi.org/10.1016/j.sbspro.2014.09.118

Nelson, M.W., Elliott, J.A., \& Tarpley, R.L. (2002). Evidence from auditors about managers' and auditors' earnings management decisions. The Accounting Review, 77, 175-202. 
https://doi.org/10.2308/accr.2002.77.s-1.175

Payne, J., \& Robb, S. (2000). Earnings management: The effect of ex-ante earnings expectations. Journal of Accounting, Auditing and Finance, 15(4), 371-392.

https://doi.org/10.1177\%2F0148558X0001500401

Peasnell, K.V., Pope, P.F., \& Young, S. (2000). Detecting earnings management using cross-sectional abnormal accruals models. Accounting and Business Research, 30(4), 313-326.

DOI: $10.1080 / 00014788.2000 .9728949$

Press, E., \& Weintrop, J. (1990). Accounting-based constraints in public and private debt agreements: Their association with leverage and importance in accounting choice. Journal of Accounting and Economics, 12(1), 65-95. https://doi.org/10.1016/0165-4101(90)90042-3

Rajgopal, S., Venkatachalam, M., \& Jiambalvo, J.J. (1999). Is institutional ownership associated with earnings management and the extent to which stock prices reflect future earnings? Retrieved from https://ssrn.com/abstract=163433 or http://dx.doi.org/10.2139/ssrn.163433

Raman, K., \& Shahrur, H. (2008). Relationship-specific investments and earnings management: Evidence from corporate suppliers and customers. The Accounting Review, 83(4), 1041-81. https://doi.org/10.2308/accr.2008.83.4.1041

Reynolds, J.K., \& Francis, J.R. (2000). Does size matter? The influence of large clients on office-level auditor reporting decisions. Journal of Accounting and Economics, 30(3), 375-400. https://doi.org/10.1016/S0165-4101(01)00010-6

Richardson, S.A., Tuna, I., \& Wu, M. (2002). Predicting earnings management: The case of earnings restatements. University of Pennsylvania, The Wharton School. Philadelphia, PA. Retrieved from https://pdfs.semanticscholar.org/74f3/035ea0bb2212c8e715780459a6f3de0bc0e2.pdf

Shen, C.H., \& Chih, H. (2007). Earnings management and corporate governance in Asia's emerging markets. Corporate Governance: An International Review, 15(5), 999-1021. https://doi.org/10.1111/j.1467-8683.2007.00624.x

Siregar, S., \& Utama, S. (2008). Type of earnings management and the effect of ownership structure, firm size, and corporate-governance practices: Evidence from Indonesia. The International Journal of Accounting, 43(1), 1- 27. https://doi.org/10.1016/j.intacc.2008.01.001

Summer, S.L., \& Sweeney, J.T. (1998). Fraudulently misstated financial statements and insider trading: An empirical analysis. The Accounting Review, 73(1), 18-33.

Sweeney, A. (1994). Debt covenant violations and managers' responses. Journal of Accounting and Economics, 17(3), 281-308. https://doi.org/10.1016/0165-4101(94)90030-2

Warfield, T.D., Wild, J.J., \& Wild, K.L. (1995). Managerial ownership, accounting choices, and informativeness of earnings. Journal of Accounting and Economics, 20(1), 61-91. https://doi.org/10.1016/0165-4101(94)00393-J

Watts, R., \& Zimmerman, J. (1990). Positive accounting theory: A ten-year perspective. The Accounting Review, 65(1), 131-157. https://doi.org/10.1006/cpac.2001.0509

Watts, R.L., \& Zimmerman, J.L. (1986). Positive accounting theory. Prentice-Hall.

Watts, R.L., \& Zimmerman, J.L. (1978). Towards a positive theory of the determination of accounting standards. The Accounting Review, 53(1), 112-134.

Young, S. (1999). Systematic measurement error in the estimation of discretionary accruals: An evaluation of alternative modeling procedures. Journal of Business, Finance and Accounting, 26(7), 833-862. https://doi.org/10.1111/1468-5957.00277 
TABLE 1

SUMMARY STATISTICS

\begin{tabular}{|l|l|l|l|l|}
\hline \multicolumn{9}{l}{$\mathrm{N}=16,084$} \\
\hline Variable & Mean & Standard Deviation & Minimum & Maximum \\
\hline AM1 & 0.306 & 0.821 & 0.001 & 9.714 \\
\hline AM2 & 0.116 & 0.168 & 0.001 & 3.239 \\
\hline CustBP1 & 0.218 & 0.206 & 0.010 & 1.000 \\
\hline CustBP2 & 0.551 & 0.278 & 0.100 & 1.000 \\
\hline size & 6.315 & 2.042 & 1.946 & 12.378 \\
\hline sales & 0.131 & 0.583 & -0.986 & 10.100 \\
\hline OCF & 0.078 & 0.176 & -3.240 & 2.395 \\
\hline Audi & 0.758 & 0.429 & 0.000 & 1.000 \\
\hline LOSS & 0.290 & 0.454 & 0.000 & 1.000 \\
\hline CRISIS & 0.147 & 0.354 & 0.000 & 1.000 \\
\hline LEV & 0.180 & 0.192 & 0.000 & 0.866 \\
\hline MB & 1.438 & 1.357 & 0.033 & 8.765 \\
\hline SOX & 0.961 & 0.194 & 0.000 & 1.000 \\
\hline
\end{tabular}

TABLE 2

RESULTS FROM MULTIVARIATE MODEL

DEPENDENT VARIABLE AM1 - MODIFIED-JONES MODEL (DECHOW ET AL., 1995)

\begin{tabular}{|c|c|c|c|c|c|c|c|}
\hline \multicolumn{8}{|c|}{$\mathrm{N}=16084$} \\
\hline \multirow[b]{2}{*}{ Variable } & \multirow[b]{2}{*}{$\begin{array}{l}\text { Predicted } \\
\text { Sign }\end{array}$} & \multicolumn{3}{|c|}{$\begin{array}{l}\text { Estimated using CustBP1 as the test } \\
\text { variable }\end{array}$} & \multicolumn{3}{|c|}{$\begin{array}{c}\text { Estimated using CustBP2 as the test } \\
\text { variable }\end{array}$} \\
\hline & & $\begin{array}{c}\text { Parameter } \\
\text { Estimate }\end{array}$ & $\begin{array}{l}\text { t-statistic } \\
\text { (p-value) }\end{array}$ & $\begin{array}{c}\text { Variance- } \\
\text { Inflation } \\
\text { Factor }\end{array}$ & $\begin{array}{c}\text { Parameter } \\
\text { Estimate }\end{array}$ & $\begin{array}{l}\text { t-statistic } \\
\text { (p-value) }\end{array}$ & $\begin{array}{c}\text { Variance- } \\
\text { Inflation } \\
\text { Factor }\end{array}$ \\
\hline Intercept & & 0.418 & $\begin{array}{l}10.14 \\
(0.00)^{* * *}\end{array}$ & 0.00 & 0.429 & $\begin{array}{l}10.67 \\
(0.00)^{* * *}\end{array}$ & 0.00 \\
\hline CustBP1 & + & 0.064 & $\begin{array}{l}2.75 \\
(0.01)^{* *}\end{array}$ & 1.01 & & & \\
\hline CustBP2 & + & & & & 0.098 & $\begin{array}{l}3.12 \\
(0.00) * * *\end{array}$ & 1.03 \\
\hline FSize & $+/-$ & -0.024 & $\begin{array}{l}-5.84 \\
(0.00) * * *\end{array}$ & 1.79 & -0.024 & $\begin{array}{l}-5.64 \\
(0.00) * * *\end{array}$ & 1.79 \\
\hline GrowthS & $+/-$ & -0.003 & $\begin{array}{l}-0.31 \\
(0.76)\end{array}$ & 1.03 & -0.005 & $\begin{array}{l}-0.46 \\
(0.64)\end{array}$ & 1.04 \\
\hline OCF & - & 0.002 & $\begin{array}{l}0.05 \\
(0.96)\end{array}$ & 1.30 & 0.003 & $\begin{array}{l}0.08 \\
(0.94)\end{array}$ & 1.30 \\
\hline AudQ & - & -0.050 & $\begin{array}{l}-2.86 \\
(0.00)^{* * *}\end{array}$ & 1.39 & -0.052 & $\begin{array}{l}-2.93 \\
(0.00) * * *\end{array}$ & 1.40 \\
\hline LOSS & + & 0.042 & $\begin{array}{l}2.53 \\
(0.01)^{* *}\end{array}$ & 1.37 & 0.041 & $\begin{array}{l}2.49 \\
(0.01)^{* *}\end{array}$ & 1.37 \\
\hline CRISIS & + & 0.298 & $\begin{array}{l}16.28 \\
(0.00)^{* * *}\end{array}$ & 1.03 & 0.298 & $\begin{array}{l}16.26 \\
(0.00)^{* * *}\end{array}$ & 1.03 \\
\hline LEV & $+/-$ & 0.094 & 2.53 & 1.23 & 0.092 & 2.49 & 1.23 \\
\hline
\end{tabular}

94 Journal of Accounting and Finance Vol. 21(4) 2021 


\begin{tabular}{|c|c|c|c|c|c|c|c|}
\hline & & & $(0.01)^{* *}$ & & & $(0.01)^{* * *}$ & \\
\hline MB & + & 0.010 & $\begin{array}{l}2.05 \\
(0.04) * *\end{array}$ & 1.14 & 0.010 & $\begin{array}{l}1.92 \\
(0.06)^{*}\end{array}$ & 1.14 \\
\hline SOX & - & -0.043 & $\begin{array}{l}-1.28 \\
(0.20)\end{array}$ & 1.04 & -0.043 & $\begin{array}{l}-1.29 \\
(0.20) \\
\end{array}$ & 1.04 \\
\hline \multicolumn{2}{|c|}{ Adjusted- $\mathrm{R}^{2}$} & \multicolumn{3}{|c|}{$2.41 \%$} & \multicolumn{3}{|c|}{$2.42 \%$} \\
\hline \multicolumn{2}{|c|}{$\begin{array}{l}\text { F-Statistic } \\
\text { (p-value) }\end{array}$} & & \multicolumn{2}{|l|}{$\begin{array}{c}40.67 \\
(0.00)^{* * *}\end{array}$} & \multicolumn{3}{|c|}{$\begin{array}{c}40.89 \\
(0.00)^{* * *}\end{array}$} \\
\hline
\end{tabular}

Note: * indicates significance at the $10 \%$ level, $* *$ indicates significance at the $5 \%$ level, and $* * *$ indicates significance at the $1 \%$ level.

TABLE 3

RESULTS FROM MULTIVARIATE MODEL DEPENDENT VARIABLE AM2 - KOTHARI (2005)

\begin{tabular}{|c|c|c|c|c|c|c|c|}
\hline \multicolumn{8}{|c|}{$\mathrm{N}=16084$} \\
\hline & & \multicolumn{3}{|c|}{$\begin{array}{l}\text { Estimated using CustBP1 as the test } \\
\text { variable }\end{array}$} & \multicolumn{3}{|c|}{$\begin{array}{l}\text { Estimated using CustBP2 as the test } \\
\text { variable }\end{array}$} \\
\hline Variable & $\begin{array}{l}\text { Predicted } \\
\text { Sign }\end{array}$ & $\begin{array}{l}\text { Parameter } \\
\text { Estimate }\end{array}$ & $\begin{array}{l}\text { t-statistic } \\
\text { (p-value) }\end{array}$ & $\begin{array}{l}\text { Variance- } \\
\text { Inflation } \\
\text { Factor }\end{array}$ & $\begin{array}{l}\text { Parameter } \\
\text { Estimate }\end{array}$ & $\begin{array}{l}\text { t-statistic } \\
\text { (p-value) }\end{array}$ & $\begin{array}{l}\text { Variance- } \\
\text { Inflation } \\
\text { Factor }\end{array}$ \\
\hline Intercept & & 0.163 & $\begin{array}{l}19.90 \\
(0.00) * * *\end{array}$ & 0.00 & 0.164 & $\begin{array}{l}20.47 \\
(0.00)^{* * *}\end{array}$ & 0.00 \\
\hline CustBP1 & + & 0.014 & $\begin{array}{l}3.06 \\
(0.00) * * *\end{array}$ & 1.01 & & & \\
\hline CustBP2 & + & & & & 0.033 & $\begin{array}{l}5.26 \\
(0.00) * * *\end{array}$ & 1.03 \\
\hline FSize & $+/-$ & -0.012 & $\begin{array}{l}-13.94 \\
(0.00)^{* * *}\end{array}$ & 1.79 & -0.011 & $\begin{array}{l}-13.65 \\
(0.00)^{* * *}\end{array}$ & 1.79 \\
\hline GrowthS & $+/-$ & -0.000 & $\begin{array}{l}-0.05 \\
(0.96)\end{array}$ & 1.03 & -0.001 & $\begin{array}{l}-0.40 \\
(0.69)\end{array}$ & 1.04 \\
\hline OCF & - & -0.010 & $\begin{array}{l}-12.04 \\
(0.00)^{* * *}\end{array}$ & 1.30 & -0.098 & $\begin{array}{l}-11.90 \\
(0.00)^{* * *}\end{array}$ & 1.30 \\
\hline Audi & - & -0.003 & $\begin{array}{l}-0.80 \\
(0.42)\end{array}$ & 1.39 & -0.003 & $\begin{array}{l}-0.98 \\
(0.33)\end{array}$ & 1.40 \\
\hline LOSS & + & 0.010 & $\begin{array}{l}2.97 \\
(0.00)^{* * *}\end{array}$ & 1.37 & 0.009 & $\begin{array}{l}2.89 \\
(0.00) * * *\end{array}$ & 1.37 \\
\hline CRISIS & + & 0.059 & $\begin{array}{l}16.05 \\
(0.00)^{* * *}\end{array}$ & 1.03 & 0.058 & $\begin{array}{l}16.00 \\
(0.00)^{* * *}\end{array}$ & 1.03 \\
\hline LEV & $+/-$ & 0.022 & $\begin{array}{l}3.05 \\
(0.00) * * *\end{array}$ & 1.23 & 0.022 & $\begin{array}{l}2.99 \\
(0.00) * * *\end{array}$ & 1.23 \\
\hline MB & + & 0.016 & $\begin{array}{l}16.32 \\
(0.00)^{* * *}\end{array}$ & 1.14 & 0.016 & $\begin{array}{l}16.05 \\
(0.00)^{* * *}\end{array}$ & 1.14 \\
\hline SOX & - & -0.011 & $\begin{array}{l}-1.69 \\
(0.09)^{*}\end{array}$ & 1.04 & -0.012 & $\begin{array}{l}-1.76 \\
(0.08) *\end{array}$ & 1.04 \\
\hline \multicolumn{2}{|c|}{ Adjusted-R ${ }^{2}$} & \multicolumn{3}{|c|}{$7.88 \%$} & \multicolumn{3}{|c|}{$7.99 \%$} \\
\hline \multicolumn{2}{|c|}{$\begin{array}{l}\text { F-Statistic } \\
\text { (p-value) }\end{array}$} & \multicolumn{3}{|c|}{$\begin{array}{c}138.65 \\
(0.00)^{* * *}\end{array}$} & \multicolumn{3}{|c|}{$\begin{array}{c}140.64 \\
(0.00)^{* * *}\end{array}$} \\
\hline
\end{tabular}

Note: * indicates significance at the $10 \%$ level, $* *$ indicates significance at the $5 \%$ level, and $* * *$ indicates significance at the $1 \%$ level. 